\title{
INNOVATIONS OF TRANSNATIONAL CORPORATIONS IN TODAY'S CONDITIONS
}

\author{
Tatiana Podolskaya \\ Maria Singkh \\ South Russian Institute of Management \\ Russian Presidential Academy of Economy and Public Administration (RANEPA), \\ Rostov-on-Don, Russia
}

The article considers the issue of innovation activities carried out by transnational corporations, as well as the impact of the COVID-19 pandemic on the innovative sphere as such. The motivation behind international companies' reorientation on the emerging economies in part of innovations in $R \& D$ and the need for unique competitive advantages over other companies is also discussed. Digitization, robotization, and automation are becoming more and more in demand and will be thus financed by transnational corporations with the increasing intensity.

Keywords: transnational corporation (TNC); innovation sector; research and development (R\&D); COVID-19 pandemic

\section{Introduction}

Innovation is one of the most important competitive advantages of any company in the 21st century (Chatzoglou \& Chftzoudes, 2018). Not only different countries, but also

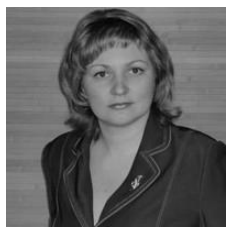

\section{Tatiana Podolskaya}

Candidate of Economic Sciences, Associate Professor, Head of Department of International Economic Relations at South Russian Institute of management of Russian Presidential Academy of Economy and Public Administration (RANEPA). The area of scientific interests includes issues of trends of modern world economy, role of transnational corporation, international financial system, as well as the problems of its regulation. Tatiana Podolskaya is the author of more than 90 scientific papers, 5 textbooks, 3 monographs.

E-mail: tv.kuraeva@mail.ru

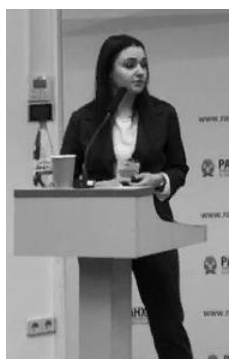

\section{Maria Singkh}

MBA candidate at South Russian Institute of management of Russian Presidential Academy of Economy and Public Administration (RANEPA).The area of scientific interests includes issues of trends of modern world economy, international financial system, problems of its regulation.

E-mail: m_singkh@mail.ru 


\section{INNOVATIONS OF TRANSNATIONAL CORPORATIONS}

international companies are interested in stimulating innovations and getting benefits from innovative results (for example, profit, new workplaces, better public image and so on). International corporations, implementing the strategy of leading innovation at the global markets, are forced to be more and more creative, considering the environment of global innovative hypercompetition. This leads to sharpening the overall process of innovative competition between the world's leading transnational corporations.

In the year 2018 the international corporations included in the top-100 largest nonfinancial TNCs invested over 350 bln USD in R\&D. This represents more than a tercile of the total investments in the latest advanced developments. At the same time, the share of $\mathrm{R} \& \mathrm{D}$ (relative to sales) among the top-100 companies in developing countries is significantly lower.

The volume of international investments in innovative projects is overall significant. During the five years before the current COVID-19 pandemic, TNCs have announced 5300 R\&D projects outside their national markets, this is more than $6 \%$ of all announced new investment projects. Noteworthy here, in the five years before that this figure was lower and equalled to 4000 (World Investment Report, 2019).

The dynamics of the innovation sector development is significantly exceeding the growth rate of the world GDP, amounting to 5,2\% in 2018 (Global Innovation Index, 2020).

\section{Main part of the research}

\section{Research and Development in a Pandemic Environment}

The COVID-19 pandemic which has caused a massive recession in the world economy, is actually having rather mixed effects on the state of the innovation sector. On the one hand, drastic slowdown in economic growth in the vast majority of countries across the world, and the losses that corporations are experiencing due to the pandemic constraints have led to an objective reduction in financial resources that could potentially be invested in innovations. On the other hand, innovations in the pharmaceutical sector and biotechnologies are being heavily funded in order to fight COVID-19. A great potential of innovative development has been identified in the healthcare sector which is gearing to combat the negative health effects from COVID-19. In the face of forced transition to a remote work mode for the absolute majority of employees worldwide, there has been a forced development of digitalization which is also supporting various innovations.

During the $20^{\text {th }}$ century, transnational corporations traditionally carried out their major innovative activities, industrial R\&D especially, only in their home countries, viewing this as an element of their own strategic dominance in an industry (Jha \& Dhanaraj, 2018). But over the past two decades TNCs have established R\&D activities in developing countries as well and have begun to consider this activity as not only a mechanism for adapting products and processes to specific local conditions (Egan, 2017). In recent years, major R\&D activities of corporations have sometimes been transferred to the emerging markets where subsidiaries of these TNCs are presented, primarily this concerns such huge markets as China and India (Yip \& McKern, 2017).

Analyzing the statistical reporting on R\&D results, it should be noted that this aspect of TNCs' activities is lagging behind only in Africa and Latin America. The key region for $\mathrm{R} \& \mathrm{D}$ of many TNCs is often Asia. If we compare developing countries only, it gets obvious 
that China, India, Czech Republic, South Korea and Israel account for the bulk of all R\&D activities.

Tab. 1 shows the evolution of R\&D expenditures in individual countries as a percentage of GDP, while Tab. 2 shows the share of R\&D activities of the US multinational corporations in their overseas affiliates.

It should be emphasized here that R\&T activities shown in Tab. 1 refer to all $R \& D$ activities in each country, including not only companies, but also the public sector, universities, research centers and the like. In this ranking, the leaders are the USA, Japan, Nordic countries, Germany, Switzerland, Israel, South Korea and China.

Table 1 - R\&D expenditures in the selected countries as a percentage of GDP, 1996-2015 (Source: Grosse, 2019)

\begin{tabular}{|l|c|c|c|c|c|c|}
\hline \multicolumn{1}{|c|}{ Country } & 1996 & 2000 & 2005 & 2010 & 2014 & 2015 \\
\hline Canada & 1,62 & 1,87 & 1,99 & 1,84 & 1,61 & - \\
\hline P.R.China & 0,57 & 0,9 & 1,32 & 1,73 & 2,05 & 2,07 \\
\hline France & 2,21 & 2,08 &, 204 & 2,18 & 2,26 & 2,23 \\
\hline Germany & 2,14 & 2,39 & 2,42 & 2,71 & 2,87 & 2,88 \\
\hline India & 0,63 & 0,74 & 0,81 & 0,8 & 0,82 & 0,63 \\
\hline Indonesia & - & 0,07 & - & 0,08 & 0,08 & - \\
\hline Israel & 5,6 & 3,93 & 4,04 & 3,93 & 4,11 & 4,27 \\
\hline Japan & 2,77 & 3,0 & 3,31 & 3,25 & 3,58 & 3,28 \\
\hline Russian Federation & 0,97 & 1,05 & 1,07 & 1,13 & 1,19 & 1,13 \\
\hline Singapore & 1,32 & 1,82 & 2,16 & 2,01 & 2,19 & - \\
\hline South Korea & 2,24 & 2,18 & 2,63 & 3,47 & 4,29 & 4,23 \\
\hline Great Britain & 1,71 & 1,72 & 1,63 & 1,69 & 1,7 & 1,73 \\
\hline The USA & 2,44 & 2,62 & 2,51 & 2,74 & 2,73 & 2,79 \\
\hline Sweden & 3,32 & 3,91 & 3,39 & 3,22 & 3,16 & 3,26 \\
\hline Switzerland & 2,45 & 2,33 & 2,68 & 2,73 & 2,97 & - \\
\hline Brazil & - & 1,0 & 1,0 & 1,16 & 1,24 & - \\
\hline Netherlands & 1,86 & 1,81 & 1,79 & 1,72 & 1,97 & 2,01 \\
\hline OECD overall & 2,14 & 2,3 & 2,22 & 2,38 & 2,42 & 2,55 \\
\hline Total in the world & 1,99 & 2,08 & 1,99 & 2,05 & 2,12 & 2,23 \\
\hline
\end{tabular}

Although the data in Tab. 2 pertain to one country only - the US, they are representative enough to characterize the general trends in foreign investments in $R \& D$ as a whole, across different countries. These data also indicate that Japan, Nordic countries, Germany, Switzerland, Israel and China, along with Great Britain and India, are among the top preferred R\&D sites of the US corporations.

With the intensifying international competition at the world markets, corporations now need unique competition advantages over other companies. Some competitive advantages may include the access to scarce natural resources, such as oil, gold or a favorable climate for primary industries, such as agriculture. The only competitive advantage that does not require any particular geographical binding and thus can be realized by companies anywhere is innovation. 
Table 2 - R\&D expenses incurred by foreign divisions of the US TNCs, by region/country, 1982-2015 (in mln USD)

(Source: U.S. Department of Commerce, 2016)

\begin{tabular}{|l|c|c|c|c|c|c|c|}
\hline & 1982 & 1995 & 2000 & 2005 & 2010 & 2015 & 2016 \\
\hline Total & 3851 & 12582 & 19758 & 27653 & 36991 & 48750 & 54797 \\
\hline Industrial RDT & 3247 & 10791 & 17822 & 23508 & 29385 & - & - \\
\hline Canada & 505 & 1068 & 1874 & 2433 & 3040 & 3178 & 3430 \\
\hline Europe & 2982 & 9144 & 12938 & 18805 & 24155 & 29825 & 31274 \\
\hline France & 332 & 1271 & 1445 & 2248 & 2171 & 2359 & 2213 \\
\hline Germany & 1079 & 3068 & 3105 & 4609 & 7039 & 8272 & 8033 \\
\hline Italy & 150 & 346 & 575 & 580 & 582 & 806 & 835 \\
\hline Netherlands & 65 & 495 & 369 & 392 & 1484 & 1478 & 1173 \\
\hline Sweden & 28 & 691 & 1335 & 1652 & 1576 & 670 & 708 \\
\hline Switzerland & 60 & 242 & 220 & 878 & 1123 & 3735 & 3865 \\
\hline Great Britain & 824 & 1935 & - & 5406 & 5157 & 5346 & 6165 \\
\hline Asia, Pacific & 238 & 1865 & 3727 & 4764 & 7210 & 10712 & 14425 \\
\hline China & - & - & - & - & 1579 & 2179 & 3428 \\
\hline India & - & - & - & - & 1377 & 2557 & 3216 \\
\hline Japan & 112 & 1286 & 1433 & 1717 & 1872 & 2070 & 2438 \\
\hline Singapore & - & 63 & 548 & 576 & 624 & 642 & 1755 \\
\hline $\begin{array}{l}\text { Latin America and } \\
\text { the Caribbean }\end{array}$ & 169 & 389 & 665 & 841 & 1465 & 2750 & 2374 \\
\hline Brazil & 97 & 249 & 250 & 405 & 791 & 1224 & 883 \\
\hline Middle East & 11 & 97 & 527 & 770 & 1063 & 2187 & 3150 \\
\hline Israel & 11 & 97 & 527 & 767 & 1060 & 2153 & 2955 \\
\hline Africa & 25 & 19 & 27 & 40 & 57 & 128 & 145 \\
\hline RSA & 23 & 17 & 22 & 31 & 43 & 94 & 38 \\
\hline
\end{tabular}

As a result, international corporations, taking advantage of new opportunities, began to invest in R\&D outside their home countries, keeping the following objectives in mind:

- lower costs of human resources, primarily intellectual capital;

- the initial adaptation of $R \& D$ to the markets of developing countries where the research is being conducted.

30-40 years ago, all innovative activities were concentrated in the home countries of transnationalized structures, and only occasional projects were local developments of products, with their adaptation to local demand conditions. There have been cases where some TNCs have acquired companies abroad that have conducted their own R\&D, so that these acquired affiliates have a sufficiently independent activity in the field of innovation. At the same time, in several cases TNC operated R\&D units outside their home countries.

\section{Classification of transnational corporations}

Given the diversity of strategies applied by TNC in relation to R\&D, all corporations can be classified into four types: 
- Adapting products originally produced in other countries to local market conditions. In this case, all $\mathrm{R} \& \mathrm{D}$ is concentrated in a country of corporate headquarters;

- R\&D carried out in developing countries which can be applied both in the home country and in other countries because local conditions in a host country may be more hospitable as compared to other options;

- $\quad$ R\&D in a place where innovative activities are carried out by other firms in the same industry to maximize the benefits from the already developed innovation environment;

Participation in the global $R \& D$ network with the aim of minimizing costs, taking into account market specificities and availability of knowledge, skills and other resources of the researchers involved in the implementation of innovation projects.

The concept of "reverse innovation" (Govindarajan \& Ravi, 2011) has been introduced in relation to TNCs' R\&D activities This is when research is carried out within a relatively low-cost developing market and is later exported to the home countries of a TNC and other countries to be then successfully commercialized.

Today, this phenomenon is largely confined to very large markets, such as China and India, with their use of qualified technical and managerial personnel. Examples of such reverse innovations include the Lullaby device for premature children (created by GE in India) or electric cars (those of General Motors and Volkswagen but developed in China). This innovative practice is likely to become much more common in the near future as emerging markets become increasingly important.

\section{Types of $R \& D$}

Since global transport and communications costs have been reducing, TNCs have shifted to the geographical redistribution of their R\&D centers, taking into account various types of research-related activities. Three types of $R \& D$ are identified in the classification of the U.S. National Research Fund (NRFR) - basic, applied, and scientific research (the process of converting information from basic and applied research into a form suitable for its economic development). Fundamental research can be equally carried out by corporations in both developing and developed countries. Basic research is usually concentrated around universities and public-funded programs. If the state wants to encourage corporations to undertake basic research in a particular area, a specific direction in $R \& D$ is often heavily subsidized by the state. In any case, basic research normally goes well beyond industrial, corporate R\&D.

Applied research, on the other hand, is precisely the kind of activity that is preferred by TNCs. Such applied innovative studies include the following directions:

- creation of new products (for local and/or international use);

- creation of new processes for production and distribution of goods and services;

- $\quad$ adapting products to local conditions;

- $\quad$ adapting processes to local conditions.

Applied research in emerging markets is a relatively small but growing part of $R \& D$ carried out by TNCs' foreign branches as their products, services, and business processes adapt to the local environment. Most R\&D in emerging markets have been implemented by some automobile firms, such as Volkswagen in China and General Motors in Brazil and 


\section{INNOVATIONS OF TRANSNATIONAL CORPORATIONS}

China, as well as in some areas of information technology and telecommunications by such firms as Motorola in Brazil, Samsung in China and IBM and Microsoft in India.

Such research development includes a number of areas related to the production of new materials, devices, systems or methods, including design, development and improvement of prototypes as well as transformation of various production processes according to specific requirements. TNCs are actively engaged in such fields of activity within the developing markets (Jha et al., 2018). This R\&D area may in fact be the most important one for emerging markets, as their efforts often involve adapting the already existing products or processes to local market requirements.

\section{Motivations behind R\&D investment}

Based on the results of studying foreign R\&D over the past three decades, funded by international corporations within their branches located in emerging markets, four types of motivations leading to the investment in these types of activities can be determined and singled out:

- international corporations invest more actively in the research activities of their affiliates in the countries where local markets are themselves quite intensive;

- as the practice of real protection of intellectual property objects has gradually spread on developing countries, an increasing number of international corporations have decided to intensify their $R \& D$ activities in their branches located in much lower-cost jurisdictions;

- R\&D activities on the side of corporate affiliates will be increased in those countries and regions where the rates of local R\&D and innovative activity are higher;

- R\&D is usually carried out within the branches located in those developing countries where TNC has a greater local presence overall.

Initially, corporate-funded R\&D in foreign branches located in developing countries was aimed at adapting corporate products and services to specific local conditions. Today however, branches within emerging markets are already implementing independent scientific programs, the results of which are subsequently distributed globally with the help of corporate headquarters and their global connections.

\section{Summary of the article}

Nowadays the most promising technological directions for the development of the innovative sphere are: automation using robotics; supply chains digitization; and layerprinting technology (Global Innovation Index, 2020). Given the optimistic forecasts, COVID-19 will soon turn into just a seasonal disease, while automation, robotization and digitalization will become strong sought-after trends, heavily financed by transnational corporate businesses.

\section{References:}

Chatzoglou, P., \& Chftzoudes, D. (2018). The role of innovation in building competitive advantages: an empirical investigation. European Journal of Innovation Management, 21 (1), 47. 
Dhanaraj C.S., \& Krishnan, R. (2018). From arbitrage to global innovation: Evolution of multinational R\&D in emerging markets. Management International Review, 58(4).

Egan, P. (2017). Globalizing Innovation: State Institutions and Foreign Direct Investment in Emerging Economies. Cambridge, Mass.: MIT Press.

Global Innovation Index (2020). Who Will Finance Innovation? Available online at: https://www.wipo.int/edocs/pubdocs/en/wipo_pub_gii_2020.pdf.

Govindarajan, V., \& Ravi, R. (2011). Reverse innovation, emerging markets, and global strategy. Global Strategy Journal, 1 (3-4), 19.

Grosse, R. (2019). Innovation by MNSs in emerging markets. Transnational Corporation, 3 (326).

Jha S., Dhanaraj, R. \& Krishnan (2018). From arbitrage to global innovation: Evolution of multinational R\&D in emerging markets. Management International Review, 58(4).

U.S. Department of Commerce (2016). Bureau of Economic Analysis, Survey of U.S. Direct Investment Abroad, Annual series. Available online at: https://www.bea.gov/international/di1usdop.

World Investment Report (2019). Special Economic Zones. UNCTAD, New York and Geneva. Available online at: https://unctad.org/system/files/official-document/wir2019_en.pdf.

Yip G., \& McKern, B. (2017). Innovation in emerging markets - the case of China. International Journal of Emerging Markets, 9(1), 10.

Paper submitted

Paper accepted for publishing

Paper published online
28 March 2021

02 May 2021

31 May 2021 